Article

\title{
Tripartite Efficacy Beliefs and Homeowner Participation in Multi-Owned Housing Governance
}

\author{
Yung Yau \\ Department of Public Policy, City University of Hong Kong, Tat Chee Avenue, Kowloon Tong, Kowloon, \\ Hong Kong 999077, China; y.yau@cityu.edu.hk; Tel.: +85-234-428-958
}

Received: 2 August 2018; Accepted: 14 September 2018; Published: 18 September 2018

\begin{abstract}
Homeowners' collective actions are essential for effective governance of multi-owned housing $(\mathrm{MOH})$ and a city's sustainable development. Yet, not all homeowners keenly participate in $\mathrm{MOH}$ governance. Unpacking why homeowners decide to participate is thus insightful. So far, little work has been done on how perceived efficacies of property management agents (PMAs) shape collective actions in $\mathrm{MOH}$ governance. Founding upon the social cognitive theory and collective interest model, a theoretical model is built to empirically examine how proxy efficacy belief influences participation behaviors of homeowners. Drawing on the findings of a survey of 2035 homeowners in Hong Kong and Macau, this study reveals that participation level correlates positively with self and group efficacy beliefs but negatively with perceived proxy efficacy. Poor performance or incapacity of the PMAs triggers a higher degree of homeowner participation. The research findings have significant policy implications for promoting a better $\mathrm{MOH}$ upkeep culture.
\end{abstract}

Keywords: resident involvement; neighborhoods; social theory; multi-owned housing; efficacy beliefs; housing governance

\section{Introduction}

Governing multi-owned housing $(\mathrm{MOH})$ necessitates interaction and cooperation among homeowners because of the social and physical sharing of the properties [1]. Yet, problems often occur in the initiation and maintenance of collective actions among homeowners, hindering housing governance. The dreadful outcomes of poor governance of $\mathrm{MOH}$ in highly-dense cities were colorfully exemplified by the local epidemics of Severe Acute Respiratory Syndrome (SARS) in Asian mega-cities in the early 2000s [2,3]. Disrepair and unauthorized alterations of sanitary systems (e.g., drain pipes and sanitary fitments) were key contributors of the quick widespread of the virus at the community level. Despite the lesson of SARS outbreak, the number of buildings in dilapidation or mismanagement continues to grow, signifying an urgent need to strengthen the governance of $\mathrm{MOH}$ and foster a care-culture of timely upkeep of buildings in Asian cities. Homeowners should take timely actions to find out the problems in their housing developments and make sensible housing governance decisions (e.g., deciding what maintenance or repair work should be carried out for the building). In this regard, homeowners' efforts are important for sustaining good upkeep and management of $\mathrm{MOH}$. More importantly, collective actions of homeowners are necessary for proper governance of $\mathrm{MOH}$ (e.g., for rights protection and housing maintenance) due to the very ownership arrangement of this type of housing, which can be in form of strata-title holding or tenancy-in-common ownership [4]. Nonetheless, outcomes of $\mathrm{MOH}$ governance resemble collective goods. As the classical collective-action theory conjectures, rational homeowners are inclined to free-ride off others in $\mathrm{MOH}$ governance [5-7]. The Olsonian logic of free-riding presages that no collective action will be realized or performed but the reality is that not all $\mathrm{MOH}$ is unmanaged. Moreover, homeowners in Hong Kong and other parts of Greater China have become more conscious of their rights in housing [8-10]. They are ready to 
take action jointly against the parties who infringe upon their interests; however, not all of these collective actions have enough participants to sustain them. Therefore, it is apparent that sustainable management of housing stock and development of civil society in a city hinge on active participation of homeowners in collective actions [11,12]. In other words, homeowners' collective actions are essential for achievement of sustainable development of a city in many different ways [13,14].

Nevertheless, there is a divergence between real life and a rigorously proved theorem, so studying the factors that drive individual homeowners to participate in $\mathrm{MOH}$ governance is worthwhile. Given that collective actions are essential for effective $\mathrm{MOH}$ governance, which is critical for sustainable management of housing stock and cultivation of civil society, this investigation meets the societal needs by illuminating ways of promoting homeowner participation. Although previous attempts have been made to identify socio-economic and psycho-social determinants of homeowner participation in $\mathrm{MOH}$ governance, the effect of perceived efficacy of a governance proxy, namely a property management company, on participation behavior or intention has been largely ignored in the literature [15]. Aiming to fill the extant literature gap, this study scrutinizes how homeowner participation is shaped by proxy efficacy belief in two post-colonial cities in China, namely Hong Kong and Macau. For empirical testing, an analytical model is formulated based upon the widely-used social cognitive theory (SCT) and collective interest model (CIM). The key research question addressed in the study is: in a collective-action setting like $\mathrm{MOH}$ governance, how do different forms of efficacy belief determine one's participation behavior? It is expected that this inquiry will offer valuable insights into advocacy of collectivism in $\mathrm{MOH}$ governance in the two cities. Research findings will help policy-makers formulate more informed policies or schemes to encourage homeowner participation.

The remaining parts of this article are structured as follows. First, relevant literature on collectivism in $\mathrm{MOH}$ governance and social cognitive theory is overviewed. The extant research gaps are also highlighted. The analytic model and methodology of the research are then portrayed. Afterwards, the survey findings and analysis results are presented. Before the article is concluded, the implications of the research findings are discussed.

\section{Literature Review}

\subsection{Collectivism and Homeowner Participation in $\mathrm{MOH}$ Governance}

Many Asian cities are dominated by multi-owned housing $(\mathrm{MOH})$ units in which the upkeep and management of the shared facilities and areas is the collective responsibility of all individual homeowners [16-18]. In MOH, homeowners are socially and financially connected to each other [19]. The governance of $\mathrm{MOH}$ thus requires a high degree of cooperation and coordination between owners [20] and, more essentially, their close involvement in housing management affairs. Proper $\mathrm{MOH}$ governance is advantageous for assuring the quality of the residential environment and residents' well-being in the long run [21,22]. It can contribute to the physical upkeep of the built environment. At the same time, it can reduce neighbor conflicts and disputes by regulating the behaviors of the residents (e.g., prohibiting littering in communal areas). To achieve these goals, participation or engagement of residents, particularly homeowners, in the governance process is indispensable. Resident participation is generally regarded to be highly beneficial to the residents themselves in different ways [23]. First, resident participation can contribute to the realization of a safe, health and livable neighborhood [24-31]. Second, resident participation can curb social problems in housing and bring on a higher level of residential satisfaction [32-37].

However, the governance of $\mathrm{MOH}$ is not straightforward. Collective action does not take place automatically, particularly when the number of stakeholders is large [5,38]. The classical Olsonian view of collective action interprets non-participation as a rational choice if no individual can exclude others from enjoying the collective goods. Given that $\mathrm{MOH}$ governance exhibits the characteristic of a public good or common-pool resource, homeowners choose to behave opportunistically when deciding unilaterally on their contributions to $\mathrm{MOH}$ governance $[7,39]$. Likewise, from a game-theory 
perspective, rational homeowners choose to not cooperate with a view to maximizing their own pay-offs [40]. Perhaps, total non-participation is an extreme situation. Sometimes, homeowners may choose to loaf, by extending less effort in $\mathrm{MOH}$ governance.

\subsection{Social Cognitive Theory (SCT) and Efficacy Beliefs}

While several empirical studies explored the factors underlying resident participation in a resident association or block organization [41-43], nearly all of them focused on socio-economic factors and ignored the collective-good nature of housing governance outcomes. Moreover, the relevance of SCT to homeowner participation in $\mathrm{MOH}$ governance has been under-researched. SCT is a social learning theory that is "much broader and more comprehensive than behaviorism and social learning" [44] (p. 63). As Bandura's agentic perspective of SCT surmises, the chance of taking an action by a rational individual is higher if the action is expected to generate net positive outcomes and lower if the action is regarded as unrewarding [45,46]. In other words, human behavior is "regulated anticipatorily by outcomes expected for given courses of action" [47] (p. 27). Rational people usually factor in various efficacy beliefs when appraising outcome expectations. Theoretically speaking, efficacy belief is about one's own sense of control and perceptions of the effectiveness, strengths and influence of different agents to realize a goal [48]. As per SCT, individuals are driven to act by their beliefs that their desired goals can result from their or other's actions.

There are various forms of efficacy belief. The three most prevalent ones are: self efficacy, collective efficacy and proxy efficacy. Self efficacy belief denotes one's self-perception of his or her own abilities to plan and perform actions entailing some specific goals [46,47]. On the other hand, collective efficacy is about how an individual perceives the capacities of his or her group to succeed in a collective effort [49]. However, collective efficacy does not result from the summation of all individual members' perceived self efficacies within a group. Collective efficacy has been characterized as "an emergent group-level property" [47] (p. 34). To put it different, it is a construct that indicates how an individual assesses the anticipated results of the joint effort of his or her group. Contrary to the case of self efficacy, "interactive, coordinative and synergetic social dynamics" within a group is a major concern when talking about collective efficacy [50] (p. 108). Whether members of a group can collaborate effectively to realize the desired collective goods or not will determine the level of group efficacy. Therefore, greater degrees of collective efficacy are usually anticipated for groups with better mutual trust and stronger cohesion among affiliates [51,52].

Regarding proxy efficacy, it concerns how an individual perceives the capabilities of an agent, which is commonly known as proxy agent, to support or stand for him or her in planning and performing actions leading to specific goals [53]. To a certain extent, direct control over a certain matter is forgone if someone relies on proxy agency. Yet, proxy control allows people to attain their desired goals even though they have limited competencies or lack resources, effort and time [46,47]. Proxy control is a "socially mediated form of perceived control that involves the relinquishing of some or all personal control to an intermediary party to help achieve specific desired outcomes" [54] (p. 426). There are several justifications for the choice of proxy control [54,55]. First, the achievement of certain desired goals requires specific skills or capacities that have not been acquired by the individuals. Second, proxy agents may be more competent, so they can assist individuals with realizing their desired goals. Third, people opt for proxy control probably because they wish to stay away from taking the burden of direct control. From above, it is reasonable to expect that people who lack skills or motivation will participate less or extend less effort to achieve the desired outcomes by themselves when the option of proxy control is available. These individuals may shift partial or full control to a proxy who can, through action and advice, enable the realization of desired goals.

In the governance of a $\mathrm{MOH}$ development, homeowners can exercise both individual agency and collective agency for direct management in order to attain a collective good-a decent, safe and hygienic living environment. Individual agency is exercised when homeowners physically partake in management affairs, say through attending owners' meetings and organizing activities for residents. 
As far as collective agency is concerned, it can be exercised by homeowners through collaboration, provision of mutual support and pooling of their resources to govern their $\mathrm{MOH}$ developments. On the other hand, homeowners can replace direct management with appointment of an external property management agent (PMA), which is typically a for-profit entity, for several reasons. For instance, the homeowners may not acquire certain know-how necessary for effective $\mathrm{MOH}$ governance and the PMA can fill the up by offering its professional expertise. Besides, the homeowners can shift the burdens of routine management to the PMA. Accordingly, homeowners exercise proxy agency by counting on a PMA's help in $\mathrm{MOH}$ governance. While the benefits of professional housing management by PMA have been widely advocated by professional bodies and governments, conclusive empirical evidence of the positive impacts of PMA on MOH governance outcomes is still absent. The Hong Kong-based study divulged that apartment buildings managed by a PMA had better safety performance compared with those without a PMA [56]. Contrarily, some argued that the existence of a PMA in a residential development did not necessarily equal good $\mathrm{MOH}$ governance [57]. The mixed evidence may be ascribed to the fact that problems like weak-principal-strong-agent relationship and rent-seeking behavior often undermine the normal functioning of a proxy agency. These agency problems are natural outcomes once homeowners substantially or fully delegate decision-making powers to a third-party PMA who strives to capitalize all opportunities to maximize its own benefit when making decisions for housing governance [7]. Nonetheless, it is important to note that in nearly all jurisdictions including the United States, China, Australia, Singapore and Hong Kong, homeowners of $\mathrm{MOH}$ developments are still held ultimately liable for the problems resulted from poor housing governance (e.g., casualties of visitors to the building and) even though they have assigned responsibility and authority of housing governance to a PMA. In other words, effective MOH governance remains heavily dependent on homeowners' active participation.

\subsection{Empirical Testing of SCT: From Private Actions to Collective Actions}

Effects of proxy control on behavioral adaption have been extensively investigated in various academic disciplines such as health psychology, education psychology and sport studies [54,58-63]. For instance, a strong correlation between an individual's intent to exercise and his or her perception of a fitness instructor's efficacy has been evidenced $[54,58,64]$. Nonetheless, a vast majority of these pervious empirical investigations have their foci on private (or individual) actions and not collective actions. The role of proxy control in individuals' decision making in a collective-action setting has been largely ignored in the literature [15]. As discussed above, since $\mathrm{MOH}$ governance necessitates collective actions, homeowners living in a $\mathrm{MOH}$ development may rely on proxy control by giving up a certain degree of direct control over housing governance affairs to the PMA. In this regard, homeowner participation in $\mathrm{MOH}$ governance can be a good example for the study on the effects of proxy efficacy belief on individuals' partaking in collective actions.

\section{Analytical Model and Research Methodology}

\subsection{Analytical Model of Homeowner Participation}

Participation in $\mathrm{MOH}$ governance is essentially similar to many types of political participation, such as voting or environmental activism, in the sense that they all involve the provision of collective goods. Therefore, the models and theories applied in such fields could offer valuable insights into the analysis of participation behaviors by homeowners in housing governance. Of the relevant theories, rational choice theory (RCT) is perhaps the most popular. The RCT of collective action was built upon Olson's collective action theory [5]. Later studies used RCT to analyze participation in political and rebellious collective actions $[65,66]$. However, these studies have been criticized for the problem of causal inference [67]. Given the problems inherent in RCT, the collective interest model (CIM) was developed to explain popular protests [68,69]. In contrast to the Olsonian version of RCT, CIM does not assume that people perceive their contributions to the realization of a collective good as insignificant. 
If an individual considers that his or her taking part can make a difference, he or she will be more likely to participate, keeping other things constant. In addition, CIM acknowledges the logic of free-riding, as it postulates that the success in the collective good provision is contingent on not only on the efforts of the individual but also on the efforts of his or her group [70]. The individual can choose to free-ride off others if he or she opines that the group as a whole is efficacious in achieving the collective good.

On account of its empirical testability, CIM has been extensively employed to expound participation behaviors of individuals in different types of collective action, including institutional collaboration [71], mass political activities [67,68,72], environmental activism [70,73,74] and combating against invasive species [75]. CIM has also been applied to explain resident participation in $\mathrm{MOH}$ governance in Hong Kong $[15,76]$. Most of these previous attempts confirmed the excellent explanatory power of CIM. Therefore, it is plausible that CIM has been widely regarded as an elaborate model for explaining collective-action behaviors [70,73,74,77].

As CIM postulates, one decides to take part in a collective action when there is a positive net difference between the expected values of participation and non-participation $[68,70]$. The expected value of the individual pivots on a number of factors, namely: (1) his or her perception about the value of the desired collective good produced if the collective action is successful; (2) his or her perceived rise in the chance of success upon his or her participation; (3) his or her perceived likelihood of the success of the group efforts in realizing the collective good; (4) his or her selective benefits of participation; and (5) his or her selective costs of participation. Accordingly, the expected value of participation, EVP, of an individual can be modeled as

$$
E V P=\left(V \times p_{i} \times p_{g}\right)+B-C
$$

where $V$ is the individual's perceived value of the desired collective good; $p_{i}$ is the individual's perceived self efficacy (i.e., perceived marginal effect of his or her involvement on the likelihood of successful provision of the collective good); $p_{g}$ is the individual's perceived group efficacy (i.e., the perceived probability of the group being successful in providing the collective good; $B$ is the total selective benefits attainable by the individual through participation; and $C$ is the total selective costs of participation borne by the individual. While SCT suggests that the individual's decision to partake in a collective action may also depend on his or her proxy efficacy belief, this factor is not embedded in conventional CIM. In this light, this study proposes to extend CIM through the inclusion of proxy efficacy belief in the model. After extension, the model becomes

$$
E V P=\left(V \times p_{i} \times p_{g} \times p_{p}\right)+B-C
$$

where $p_{p}$ is the individual's perceived proxy efficacy (i.e., perception about to what extent the successful provision of the collective good is influenced by a proxy agent). In light of the potential difficulties in empirically estimating a multiplicative-form model, the extended CIM portrayed in Equation (2) is transformed into an additive linear functional form as follows by making reference to previous empirical studies $[15,70,71,74,76]$ :

$$
E V P=V+p_{i}+p_{g}+p_{p}+B+C
$$

\subsection{Variable Measurement}

In the context of $\mathrm{MOH}$ governance, it is reasonable to take the collective good as the desirable outcome of housing governance, resulting in qualities like high standard of building safety, good environmental hygiene and quiet living environment. As Table 1 illustrates, the variables in Equation (3) are operationalized to facilitate model estimation and data collection. According to the ideas underpinning CIM, a rational homeowner will choose to participate more actively or frequently in $\mathrm{MOH}$ governance if he or she has a higher expected value of participation. Given that the dependent variable $E V P$ is an unobservable construct, it is proxied by a self-reported participation level for the 
purpose of model estimation. Following the practice adopted in other Hong Kong-based empirical studies [15,76], the frequencies of four activities most commonly identified in $\mathrm{MOH}$ governance are used to measure one's participation level. These activities are (1) organizing resident activities; (2) voting at owners' meetings; (3) expressing views at owners' meetings; and (4) attending owners' meetings. For each activity, a four-point scale $(1=$ never; $2=$ seldom or rarely; $3=$ sometimes; and $4=$ very frequently or often) is used to gauge the participation frequency. The unweighted average of the points assigned for the four $\mathrm{MOH}$ governance activities is then calculated to give the overall participation level of a homeowner, PL (Cronbach's $\alpha=0.768)$.

Likewise, the perceived value of the collective good, $V$, cannot be easily observable or measurable [78,79]. Therefore, an indirect approach is used to measure this variable. On the account that the main goal of the $\mathrm{MOH}$ governance is to ensure the living environment in a housing development to be pleasurable to the residents, a homeowner is likely to assign a greater value to the collective good of $\mathrm{MOH}$ governance if the gap between his or her expectation and the actual situation is larger. Following this line of thought, the variable $V$ is estimated by an individual homeowner's level of frustration with the governance outcome in his or her MOH development, DISC. Homeowner discontent is evaluated in seven different aspects, namely upkeep of building services, structural safety, fire safety, quietness, environmental hygiene, security and management of landscaped areas and recreational facilities. The homeowner is asked to evaluate his or her dissatisfaction levels to these seven aspects using a four-point scale (with 1 = very satisfied; 2 = satisfied; 3 = dissatisfied; and $4=$ very dissatisfied). The overall score for DISC is obtained by simple averaging of the points received in these seven aspects (Cronbach's $\alpha=0.771$ ). It is hypothesized that a homeowner participates more actively in $\mathrm{MOH}$ governance if his or her overall level of discontent is higher.

Table 1. Operationalized variables for the empirical analysis.

\begin{tabular}{cc}
\hline CIM Variable & Operationalized Variable(s) \\
\hline Expected value of participation $(E V P)$ & Level of participation $(P L)$ \\
Perceived value of collective good $(V)$ & Discontent level (DISC) \\
Self efficacy $\left(p_{i}\right)$ & Outcome influence (INFL) \\
Group efficacy $\left(p_{g}\right)$ & Group cohesion $(C O H E)$ \\
& Expected reciprocity $(E X R E)$ \\
Proxy efficacy $\left(p_{p}\right)$ & Property management agent efficacy $(E P M A)$ \\
Selective benefits $(B)$ & Residential attachment $(R E A T)$ \\
& Social norm $(N O R M)$ \\
Selective costs $(C)$ & Committee membership $(M E M)$ \\
& Age $(A G E)$ \\
& Gender $(M A L E)$ \\
& Personal monthly income $(I N C)$ \\
& Education level $(E D U)$ \\
\hline
\end{tabular}

A homeowner's perception of his or her self efficacy, INFL, alludes to the extent to which he or she believes that the probability of achieving the collective good can be increased by his or her partaking in $\mathrm{MOH}$ governance [75]. A four-point Likert scale (with $1=$ strongly disagree; $2=$ disagree; $3=$ agree; and $4=$ strongly agree) is used to indicate if the homeowner agrees with the statement "your participation in housing governance will make a difference in the quality of your housing development." Homeowners with a stronger perception of personal influence on the governance result are expected to be more participative to take $\mathrm{MOH}$ governance actions. As for group efficacy belief, it is commonly believed to be associated with the levels of group cohesion, $\mathrm{COHE}$ and expected reciprocity, EXRE, perceived by the individual group member $[70,74,80]$. From this premise, these two variables will measure a homeowner's perceived level of group efficacy. The perceived level of group cohesion is measured based on the homeowner's agreement with four statements "residents in your housing development look after each other," "your neighbors and you want the same things from the housing development," "if there is a problem in your housing development, residents can get it solved" and "residents in your housing development generally get along well with each other" using 
a four-point Likert scale (with $1=$ strongly disagree; 2 = disagree; 3 = agree; and $4=$ strongly agree). The overall COHE score for each homeowner is attained from averaging the points assigned to these four statements (Cronbach's $\alpha=0.859$ ). To gauge EXRE, the homeowner is asked about his or her view towards the statement "other homeowners in your housing development will participate in housing governance as you do" using a four-point Likert scale (with 1 = strongly disagree; 2 = disagree; $3=$ agree; and $4=$ strongly agree). For good $\mathrm{MOH}$ governance, homeowner participation plays an important role but collaboration among individual homeowners is also vital. If there is no cohesion or unification among the homeowners, it is hard for them to act and work jointly towards the same goals. On this account, the homeowner may not be motivated to participate in $\mathrm{MOH}$ governance when he or she feels that the chance of success in achieving the collective good by the group is slim for the deficiency in consonant views and cooperation among the homeowners. It is hence anticipated that $P L$ is positively correlated with COHE and EXRE, ceteris paribus.

A homeowner's proxy efficacy belief is operationalized through a measure of how he or she perceives the efficacy of a third-party PMA, EPMA. This operationalized variable is gauged with the homeowner's level of agreement with the statement "your PMA is competent to manage your housing development properly." Again, a four-point scale (with 1 = strongly disagree; 2 = disagree; $3=$ agree; and $4=$ strongly agree) is used to indicate the agreement level. Homeowners with greater perceived proxy efficacy are expected to be more involved in housing governance activities, keeping other things constant.

The category of selective benefits, $B$, is broken down into three operationalized variables. The first one is the homeowner's perceived residential attachment, REAT. To gauge this variable, a homeowner is asked to state his or her agreement with the statement "you are proud of being a resident in your housing development" based on a four-point Likert scale (with 1 = strongly disagree; 2 = disagree; 3 = agree; and $4=$ strongly agree). Residential attachment is about the affective connection established between a resident and his housing community and the resident's feeling of pride of his housing community [81,82]. To a very large extent, it is related to the resident's identification with his or her residential neighborhood. Therefore, a homeowner can express and reinforce his or her feeling of attachment to the $\mathrm{MOH}$ development through active engagement in various affairs related to housing governance. The homeowner is more motivated to participate when he or she attaches to and identifies with his or her housing development [83]. The second one is the social norm, NORM. Since non-conformance to social norms may bring social sanctions like social rejection, norm conformity is thought to offer the conformers selective benefits. To gauge the variable NORM, a homeowner is asked if he or she agrees that partaking in housing governance is a responsibility of every homeowner using a four-point Likert scale (with $1=$ strongly disagree; $2=$ disagree; $3=$ agree; and $4=$ strongly agree). The last variable for indicating selective benefit of participation is the membership in a committee of the homeowner association, MEM. It is a dummy variable that equals 1 if a homeowner is a member of a committee of his or her $\mathrm{MOH}$ development's homeowner association and zero if otherwise. Again, committee membership is related to a homeowner's social identity associated with his or her membership group. One can gain the expressive benefits from the positive social identity of a group or committee membership through active involvement in the group [84]. Other things being constant, participation is expected to be more intensive if a homeowner holds membership in a homeowner association's committee and if he or she perceives a stronger residential attachment to the housing development. Additionally, if a homeowner regards participation as a norm, a higher level of participation level is envisaged.

Time is, in general, the major selective cost of participation in a collective endeavor. For an individual, whether the selective costs of participation, $C$, is affordable or not depends on a set of factors, such as the availability of capital, time, skills and knowledge required for his or her effectual involvement [85]. In this light, $C$ can be proxied by a set of socio-demographic factors for the operationalization purpose [73]. In this study, four variables, namely age, gender, personal income and educational attainment, are employed. A six-category scale (with $6=65$ years old or above; 
$5=55-64$ years old $; 4=45-54$ years old $; 3=35-44$ years old $; 2=25-34$ years old; and $1=18-24$ years old) is employed to indicate a homeowner's age group, AGE. Concerning a homeowner's gender, $M A L E$ is a dummy variable which equals 1 for male and zero if otherwise. As for the income level, a six-category measure (with $6=\mathrm{HK} \$ / \mathrm{MOP} 50,000$ or above; $5=\mathrm{HK} \$ / \mathrm{MOP} 40,000-49,999$; $4=\mathrm{HK} \$ / \mathrm{MOP} 30,000-39,999 ; 3=\mathrm{HK} \$ / \mathrm{MOP} 20,000-29,999 ; 2=\mathrm{HK} \$ / \mathrm{MOP} 10,000-19,999$; and $1=$ below $\mathrm{HK} \$ / \mathrm{MOP} 10,000)$ is adopted to indicate the average monthly personal income of a homeowner, INC. The highest educational attainment of a homeowner, $E D U$, is gauged using a six-category scale (with $6=$ degree or above; $5=$ sub-degree post-secondary education; $4=$ matriculation; $3=$ upper secondary school; $2=$ lower secondary school; and 1 = primary school or below). While there is no prior expectation about the effects of gender and age on participation level, we envisage that homeowners with higher personal incomes participate less actively because of higher opportunity costs of time. On the other hand, homeowners with higher education levels are anticipated to be more active participants. They are more willing to be engaged in the governance activities because they tend to have a better understanding of the importance of proper $\mathrm{MOH}$ governance and possess better know-how regarding housing governance.

After operationalization, the model becomes

$$
\begin{aligned}
& P L=\alpha_{0}+\alpha_{1} D I S C+\alpha_{2} I N F L+\alpha_{3} C O H E+\alpha_{4} E X R E+\alpha_{5} E P M A+\alpha_{6} R E A T+\alpha_{7} N O R M+ \\
& \alpha_{8} M E M+\alpha_{9} A G E+\alpha_{10} M A L E+\alpha_{11} I N C+\alpha_{12} E D U+\alpha_{13} S C A L E+\alpha_{14} B A G E+\alpha_{15} H K+\varepsilon
\end{aligned}
$$

where $\varepsilon$ is the stochastic term and $\alpha_{i}$ (for $i=0,1,2, \ldots, 15$ ) are coefficients to be estimated. SCALE refers to development scale of the $\mathrm{MOH}$ development the homeowner is living in. It is gauged by the total number of residential units the development accommodates. BAGE, measured in years, denotes the age of the homeowner's housing development and this variable is taken as the time gap between the date when the occupation permit for development was issued and the date of survey. $H K$ is a dummy variable which is equal to 1 when the homeowner lives in a $\mathrm{MOH}$ development in Hong Kong and zero if otherwise. The inclusion of these three variables helps control the contextual differences among $\mathrm{MOH}$ developments in Hong Kong and Macau as these differences may affect homeowner participation in some way. Before the model estimation, variable rescaling is needed in order to ensure that the analysis results can be more easily interpreted. A continuous linear $[0,1]$ scale is applied to all non-dichotomous variables.

\subsection{Data Collection}

For empirical testing of the analytical model elaborated in the previous section, data were collected in Hong Kong and Macau. These two post-colonial cities in China are good laboratories for the research for two reasons. First, the private housing markets there are dominated by $\mathrm{MOH}$ developments of different scales. Second, homeowner participation in $\mathrm{MOH}$ governance there is purely voluntary. Online structured questionnaire surveys were conducted in Hong Kong in 2015 and in Macau in 2016. A questionnaire was developed to obtain the information needed for model estimation. Before the surveys officially started, the questionnaire had been pretested and modified in response to the testers' feedback. A letter was sent to the sampled households in selected $\mathrm{MOH}$ developments to invite the respective household heads to complete an online survey.

In the current study, only large- and medium-scale $\mathrm{MOH}$ developments (developments with not less than 400 dwellings units in Hong Kong and not less than 200 dwelling units in Macau) were targeted for more practical employability of the implications of the research findings. It is generally believed that improvements in housing governance are more likely in this group of housing developments because of the relatively higher levels of affluence of the homeowners in these estates. The local authorities in Hong Kong and Macau could first tackle the governance problems in this type of housing by promoting homeowner participation so as to delay the intensification of overall housing mismanagement problems. Local authorities could then direct resources to deal 
with small-scale residential developments which are usually more problematic in terms of housing governance. A multi-stage sampling approach was adopted for selecting the households for the surveys. Fifteen $\mathrm{MOH}$ developments in Hong Kong and 12 in Macau meeting the selection criteria were randomly selected in the first place. Table 2 summarizes the characteristics of these $27 \mathrm{MOH}$ developments. There were altogether 44,563 and 12,325 dwelling units in sampled MOH developments in Hong Kong and Macau, respectively. Among these dwelling units, 5000 in Hong Kong and 2500 in Macau were randomly selected for the surveys. Eventually, 1457 (29.1\%) and 578 (23.1\%) replies which were complete and valid were returned in Hong Kong and Macau, respectively.

Table 2. Characteristics of the sampled MOH developments.

\begin{tabular}{cccc}
\hline City & Indicator & Number of Dwelling Units & Building Ages (Years) \\
\hline \multirow{4}{*}{ Hong Kong } & Maximum & 5728 & 35 \\
& Mean & 2970.87 & 25.73 \\
& Minimum & 840 & 13 \\
& $\sigma$ & 1404.32 & 7.53 \\
\hline \multirow{4}{*}{ Macau } & Maximum & 2228 & 27 \\
& Mean & 1027.08 & 19.83 \\
& Minimum & 526 & 4 \\
& $\sigma$ & 505.13 & 7.51 \\
\hline \multirow{4}{*}{ Overall } & Maximum & 5728 & 35 \\
& Mean & 2106.96 & 23.11 \\
& Minimum & 526 & 4 \\
& $\sigma$ & 1462.41 & 7.49 \\
\hline
\end{tabular}

\section{Findings and Analysis Results}

\subsection{Survey Findings}

Table 3 summarizes the socio-demographic characteristics of the respondents. 24 respondents $(1.6 \%)$ in Hong Kong and 11 respondents (1.9\%) in Macau were committee members of their respective owners' associations. Table 4 shows that the means of most variables laid between 0.4 and 0.6 after rescaling. No noticeable problem of multicollinearity among the explanatory variables is spotted in the dataset after inspecting the correlation matrix.

Table 3. Socio-demographic characteristics of the respondents.

\begin{tabular}{|c|c|c|c|c|c|c|}
\hline \multirow{2}{*}{ Variable } & \multicolumn{2}{|c|}{ Hong Kong $(n=1457)$} & \multicolumn{2}{|c|}{ Macau $(n=578)$} & \multicolumn{2}{|c|}{ Overall $(n=2035)$} \\
\hline & Count & $\%^{1}$ & Count & $\%^{1}$ & Count & $\%^{1}$ \\
\hline \multicolumn{7}{|c|}{ Age } \\
\hline Male & 1070 & $73.4 \%$ & 336 & $58.1 \%$ & 1406 & $69.1 \%$ \\
\hline Female & 387 & $26.6 \%$ & 242 & $41.9 \%$ & 629 & $30.9 \%$ \\
\hline $18-24$ years old & 77 & $5.3 \%$ & 33 & $5.7 \%$ & 110 & $5.4 \%$ \\
\hline $25-34$ years old & 239 & $16.4 \%$ & 103 & $17.8 \%$ & 342 & $16.8 \%$ \\
\hline $35-44$ years old & 363 & $24.9 \%$ & 137 & $23.7 \%$ & 500 & $24.6 \%$ \\
\hline $45-54$ years old & 455 & $31.2 \%$ & 171 & $29.6 \%$ & 626 & $30.8 \%$ \\
\hline $55-64$ years old & 241 & $16.5 \%$ & 99 & $17.1 \%$ & 340 & $16.7 \%$ \\
\hline 65 years old or above & 82 & $5.6 \%$ & 35 & $6.1 \%$ & 117 & $5.7 \%$ \\
\hline \multicolumn{7}{|c|}{ Gender } \\
\hline Male & 1070 & $73.4 \%$ & 336 & $58.1 \%$ & 1406 & $69.1 \%$ \\
\hline Female & 387 & $26.6 \%$ & 242 & $41.9 \%$ & 629 & $30.9 \%$ \\
\hline \multicolumn{7}{|c|}{ Monthly income } \\
\hline Below HK\$/MOP 9999 & 61 & $4.2 \%$ & 22 & $3.8 \%$ & 83 & $4.1 \%$ \\
\hline HK\$/MOP 10,000-19,999 & 151 & $10.4 \%$ & 60 & $10.4 \%$ & 211 & $10.4 \%$ \\
\hline HK\$/MOP 20,000-29,999 & 338 & $23.2 \%$ & 114 & $19.7 \%$ & 452 & $22.2 \%$ \\
\hline HK\$ / MOP 30,000-39,999 & 449 & $30.8 \%$ & 195 & $33.7 \%$ & 644 & $31.6 \%$ \\
\hline HK\$ /MOP 40,000-49,999 & 359 & $24.6 \%$ & 140 & $24.2 \%$ & 499 & $24.5 \%$ \\
\hline HK\$/MOP 50,000 or above & 82 & $5.6 \%$ & 35 & $6.1 \%$ & 117 & $5.7 \%$ \\
\hline \multicolumn{7}{|c|}{ Education level } \\
\hline Primary school or below & 69 & $4.7 \%$ & 12 & $2.1 \%$ & 81 & $4.0 \%$ \\
\hline Lower secondary school & 157 & $10.8 \%$ & 25 & $4.3 \%$ & 182 & $8.9 \%$ \\
\hline Upper secondary school & 445 & $30.5 \%$ & 185 & $32.0 \%$ & 630 & $31.0 \%$ \\
\hline Matriculation & 254 & $17.4 \%$ & 95 & $16.4 \%$ & 349 & $17.1 \%$ \\
\hline Sub-degree post-secondary education & 384 & $26.4 \%$ & 180 & $31.1 \%$ & 564 & $27.7 \%$ \\
\hline Bachelor degree or above & 148 & $10.2 \%$ & 81 & $14.0 \%$ & 229 & $11.3 \%$ \\
\hline
\end{tabular}

${ }^{1}$ Owing to rounding, not all the percentages add up to $100 \%$ for each characteristic. 
Table 4. Mean survey responses after rescaling.

\begin{tabular}{ccccccc}
\hline \multirow{2}{*}{ Variable } & \multicolumn{2}{c}{ Hong Kong $(\boldsymbol{n}=\mathbf{1 4 5 7})$} & \multicolumn{2}{c}{ Macau $(\boldsymbol{n}=\mathbf{5 7 8})$} & \multicolumn{2}{c}{ Overall $(\boldsymbol{n}=\mathbf{2 0 3 5})$} \\
\cline { 2 - 7 } & Mean & $\boldsymbol{\sigma}$ & Mean & $\boldsymbol{\sigma}$ & Mean & $\boldsymbol{\sigma}$ \\
\hline$P L$ & 0.55 & 0.19 & 0.52 & 0.19 & 0.54 & 0.19 \\
$D I S C$ & 0.53 & 0.17 & 0.53 & 0.17 & 0.53 & 0.17 \\
INFL & 0.51 & 0.25 & 0.54 & 0.25 & 0.52 & 0.25 \\
COHE & 0.49 & 0.20 & 0.50 & 0.18 & 0.50 & 0.19 \\
$E X R E$ & 0.48 & 0.26 & 0.48 & 0.18 & 0.48 & 0.24 \\
$E P M A$ & 0.49 & 0.24 & 0.49 & 0.25 & 0.49 & 0.24 \\
REAT & 0.51 & 0.27 & 0.51 & 0.26 & 0.51 & 0.27 \\
NORM & 0.50 & 0.24 & 0.50 & 0.28 & 0.50 & 0.25 \\
MEM & 0.02 & 0.13 & 0.02 & 0.14 & 0.02 & 0.13 \\
$A G E$ & 0.51 & 0.25 & 0.51 & 0.26 & 0.51 & 0.25 \\
MALE & 0.73 & 0.44 & 0.58 & 0.49 & 0.69 & 0.46 \\
$I N C$ & 0.56 & 0.25 & 0.58 & 0.25 & 0.57 & 0.25 \\
EDU & 0.56 & 0.27 & 0.62 & 0.25 & 0.58 & 0.26 \\
SCALE & 0.58 & 0.71 & 0.14 & 0.10 & 0.45 & 0.30 \\
BAGE & 0.26 & 0.24 & 0.52 & 0.22 & 0.65 & 0.25 \\
$H K$ & 1.00 & 0.00 & 0.00 & 0.00 & 0.72 & 0.45 \\
\hline
\end{tabular}

\subsection{Results of Regression Analyses}

The model specified in Equation (4) is estimated using the whole dataset with the ordinary least square (OLS) technique. In addition, OLS analyses are run on Hong Kong's and Macau's data separately, with the contextual variable $H K$ being taken away. The results of the OLS analyses are presented in Table 5 where Models (1), (2) and (3) represent the estimations using the combined dataset, Hong Kong's dataset and Macau's dataset respectively. The OLS analyses return adjusted $R^{2}$ of 0.42-0.47. These values are comparable with many other CIM-based empirical studies, implying reasonably high explanatory power of the models. Among the three models, Model (2), that is, the Hong Kong-based model, had the highest adjusted $R^{2}$. Generally speaking, the results of the OLS analyses confirm the central surmises of CIM. In the three models, the estimated coefficients of EXRE, COHE, INFL and DISC are found to be positive and statistically significant $(p<0.01)$. These results reveal that participation level has a positive relationship with dissatisfaction, perceived levels of personal influence, expected reciprocity and group cohesion. The perceived level of proxy efficacy, $E P M A$, is also evidenced to exert a statistically significant bearing on participation level $(p<0.05$ at least) but its influence is negative. That means the responding homeowners who participate less actively in $\mathrm{MOH}$ governance generally perceived their PMAs as being more efficacious.

As far as selective benefit variables (i.e., REAT, NORM and MEM) are concerned, their estimated coefficients are also revealed as positive and statistically significant $(p<0.01)$. These results signify that a sense of residential attachment, social norm and committee membership are important considerations in the homeowners' decision-making on participation in $\mathrm{MOH}$ governance. On the other hand, in all three models, no selective cost variable (i.e., $A G E, S E X, P I N C$ or EDU) is found to have a significant bearing on the participation level (even at the $10 \%$ level). Regarding the contextual variables, development scale is found to have positive and significant effect on $P L$ in all models $(p<0.01)$. That means homeowners living in larger housing developments tended to be more active in $\mathrm{MOH}$ governance affairs. Participation level is found

Building age did not pose any significant influence on participation level. The estimation of Model (1) also divulges that there was no significant difference in the participation levels between respondents from Hong Kong and those from Macau, keeping other things constant. Among those variables found to have significant impacts on PART, COHE has the largest estimated coefficient (from 0.3115 to 0.3147 ), followed by DISC (from 0.2765 to 0.2928 ) and MEM (from 0.2304 to 0.2341 ). Such findings signify that these factors were the strongest predictors of participation level of the responding homeowners in $\mathrm{MOH}$ governance in the two cities. 
Table 5. Estimation results of the OLS analyses.

\begin{tabular}{|c|c|c|c|c|c|c|}
\hline \multirow{2}{*}{ Variable } & \multicolumn{2}{|c|}{ Model (1) } & \multicolumn{2}{|c|}{ Model (2) } & \multicolumn{2}{|c|}{ Model (3) } \\
\hline & Coefficient & $t$-Statistic & Coefficient & $t$-Statistic & Coefficient & $t$-Statistic \\
\hline Constant & 0.0647 & $2.8588^{1}$ & 0.0777 & $2.8241^{1}$ & 0.0243 & 0.4954 \\
\hline DISC & 0.2874 & $12.1378^{1}$ & 0.2928 & $10.6223^{1}$ & 0.2765 & 6.2189 \\
\hline INFL & 0.0873 & $5.8706^{1}$ & 0.0712 & $3.9789^{1}$ & 0.1158 & $4.1470^{1}$ \\
\hline $\mathrm{COHE}$ & 0.3147 & $15.0021^{1}$ & 0.3146 & $12.9099^{1}$ & 0.3115 & $7.3560^{1}$ \\
\hline EXRE & 0.0637 & $4.5748^{1}$ & 0.0370 & $2.4904^{1}$ & 0.1834 & $4.8363^{1}$ \\
\hline$E P M A$ & -0.0443 & $-3.3912^{1}$ & -0.0380 & $-2.4911^{2}$ & -0.0524 & $-2.0932^{2}$ \\
\hline REAT & 0.0384 & $3.3350^{1}$ & 0.0333 & $2.5074^{2}$ & 0.0605 & $2.6614^{1}$ \\
\hline NORM & 0.1289 & $8.0730^{1}$ & 0.1486 & $7.5902^{1}$ & 0.1027 & $3.8200^{1}$ \\
\hline$M E M$ & 0.2341 & $12.1029^{1}$ & 0.2323 & $9.2135^{1}$ & 0.2304 & $8.4914^{1}$ \\
\hline$A G E$ & -0.0067 & -0.5596 & -0.0089 & -0.6425 & -0.0057 & -0.2370 \\
\hline$M A L E$ & 0.0108 & 1.5090 & 0.0079 & 0.9049 & 0.0182 & 1.4465 \\
\hline$I N C$ & -0.0069 & -0.5438 & 0.0023 & 0.1602 & -0.0354 & -1.3234 \\
\hline$E D U$ & 0.0107 & 0.8788 & 0.0117 & 0.8232 & 0.0052 & 0.2173 \\
\hline SCALE & 0.0443 & $3.3501^{1}$ & 0.0507 & $3.7055^{1}$ & 0.0488 & $0.7904^{1}$ \\
\hline$B A G E$ & -0.0148 & -1.0815 & -0.0107 & -0.7117 & -0.0232 & -0.7456 \\
\hline$H K$ & 0.0144 & 1.4469 & - & - & - & - \\
\hline$R^{2}$ & \multicolumn{2}{|c|}{0.4576} & \multicolumn{2}{|c|}{0.4729} & \multicolumn{2}{|c|}{0.4385} \\
\hline Adjusted $R^{2}$ & \multicolumn{2}{|c|}{0.4536} & \multicolumn{2}{|c|}{0.4678} & \multicolumn{2}{|c|}{0.4246} \\
\hline F-statistic & \multicolumn{2}{|c|}{$113.5690^{1}$} & \multicolumn{2}{|c|}{$92.4015^{1}$} & \multicolumn{2}{|c|}{$31.4112^{1}$} \\
\hline No. of observations & \multicolumn{2}{|c|}{2035} & \multicolumn{2}{|c|}{1457} & \multicolumn{2}{|c|}{578} \\
\hline
\end{tabular}

${ }^{1}$ Coefficient or test statistic is significant at the $1 \%$ level. ${ }^{2}$ Coefficient or test statistic is significant at the $5 \%$ level.

\section{Discussion and Implications}

Evidently, the results of the empirical analyses substantiate the applicability of the CIM in explaining homeowner participation in $\mathrm{MOH}$ governance in Hong Kong and Macau. Homeowners who were more dissatisfied with the outcome of $\mathrm{MOH}$ governance were inclined to participate more keenly in the governance of their housing developments. It was likely that homeowners might remain inactive or passive in the housing governance affairs when there was nothing intolerably problematic in their living environment. When they faced problems that they could not tolerate anymore, they would seek opportunities to voice their opinion or take action. In other words, discontent catalyzed homeowners' involvement in $\mathrm{MOH}$ governance. Such findings actually echo the arguments of other studies that residents tend to be reactive rather than proactive in housing management affairs or neighborhood issues [86-89].

Regarding efficacy beliefs, homeowners' decision to take part in $\mathrm{MOH}$ governance depended on both self efficacy and collective efficacy. Such findings are similar to those of previous empirical studies [15,76]. When homeowners thought they could make a difference in the collective outcomes of $\mathrm{MOH}$ governance, their participation was more likely, ceteris paribus. This means that even if an individual homeowner valued the collective good of proper $\mathrm{MOH}$ governance as high, he or she might not actively partake in the associated activities if he or she regards himself or herself as impotent to make any difference in the collective outcome. The more efficacious the homeowner perceived, the more keenly he or she was engaged in housing governance activities. Contrariwise, a lower level of participation would be resulted if the homeowner saw himself or herself as incapable of affecting the end results. By the same token, when homeowners did not believe that their group's collective efforts were productive, they might choose not to participate. Partaking was less likely if the homeowners perceived that their groups could not work effectually towards the collective goals of $\mathrm{MOH}$ governance. While the results of the OLS analyses robustly confirm that perceived self efficacy shapes a homeowner's decision on participation in $\mathrm{MOH}$ governance, the effect of this factor is rather marginal compared with group cohesion. As shown by the magnitudes of the estimated coefficients, the influence of INFL is significantly slighter than that of COHE $(p<0.01)$. This differential of the influence epitomizes the free-riding logic underlying the CIM-an individual will opt for not partaking in a collective endeavor if he or she opines that the group cannot work efficaciously towards the collective goal. The effect of COHE on PL is more than triple that of INFL, implying that 
partaking may be still unlikely if a homeowner has a strong self efficacy belief but a very weak group efficacy belief.

Concerning proxy efficacy, its effects on participation level are negative in all models, which is contrary to the researcher's expectation. Very probably, holding a strong efficacy belief in their PMAs, homeowners went for staying back and leaving the housing governance responsibilities to their PMAs, who were thought to be more competent in $\mathrm{MOH}$ governance. The marginal influence of proxy efficacy belief on participation level was similar to that of self efficacy belief but significantly lower than that of collective efficacy belief. From the analysis results, one may infer that in a cooperative relational context like $\mathrm{MOH}$ governance, the negative effects of proxy efficacy may offset or even outweigh the positive effect of self efficacy in motivating individual involvement [90]. Over-reliance on proxy control may inhibit self-management [91]. It may "impede the cultivation of personal competencies" [46] (p. 13) and reduce "the opportunities to build skills needed for efficacious action" [55] (p. 17).

Furthermore, all variables proxying selective benefits are found to correlate positively with participation level. Again, these findings support that homeowner participation in $\mathrm{MOH}$ governance is, to a large extent, incentive-driven. Committee membership was the strongest predictor of $P L$ among the three selective benefit variables. This means that membership in an owners' association committee brings very a strong expressive incentive to homeowners to engage in $\mathrm{MOH}$ governance. Moreover, the expressive incentive from strong attachment to a residential community also motivates homeowners there to contribute. The more proud a homeowner is of being a part of a residential community, the greater stake he or she will have in $\mathrm{MOH}$ governance and the stronger their incentive to take part in the governance activities. In addition, norm conformity is found to be an imperative driver for homeowner participation. Very likely, homeowners are afraid of being socially rejected or isolated if they think that homeowner participation is a kind of prescriptive norm in the two cities. On the other hand, all the selective cost variables are evidenced to bear no significant impact on the participation behaviors of $\mathrm{MOH}$ homeowners. Decision-making on participation in $\mathrm{MOH}$ governance was not gender- or age-sensitive. It was also unrelated to the homeowners' education levels. Although previous studies evidenced a positive association between income and participation levels, personal income exerted no significant influence on the degree of homeowner participation in this research [70].

Some insights can be drawn from the results of the exploratory analysis. To promote active homeowner participation in $\mathrm{MOH}$ governance, it can be useful to build up the self efficacy beliefs of homeowners. This can be achieved through a community education program that equips homeowners with the skills and knowledge necessary for $\mathrm{MOH}$ governance. The community education program is also important for another reason. In spite of the extensive empirical evidence of the positive correlation between proxy efficacy and individuals' participation or effort in private actions [58,62], this research reveals the downside of proxy agency [53]. Individuals might fall into a state of proxy-dependency "wherein it is easier to obtain, or they have become accustomed to obtaining, desired outcomes by using the proxy agent rather than developing and using their own skills" [92] (p. 95). To avoid homeowners' over-reliance on PMA, it is necessary for the governments to convey important messages to homeowners about $\mathrm{MOH}$ governance, such as "homeowner participation is vital for successful $\mathrm{MOH}$ governance" and "homeowners themselves should be equipped with the skills and knowledge of self-management of their housing developments."

On the other hand, in order to motivate homeowners to partake in $\mathrm{MOH}$ governance affairs, what is more important is the fostering of a cooperative climate within a $\mathrm{MOH}$ community. The analysis results show that perceived group cohesion has greater marginal influence on the level of homeowner participation than self efficacy belief. A multi-pronged community-building approach should, therefore, be adopted to cultivate a culture of homeowner participation. From the hardware side, the planning and design of a $\mathrm{MOH}$ development should allow adequate facilities and space to enable social interactions among the residents. From the software side, cohesion and mutual trust of the residents can be boosted or preserved through various ways. For example, owners' associations or neighborhood-based bodies can organize social activities regularly to let the residents come together 
and know each other more. Inductions can be offered to new residents to create a sense of friendliness and a sense of solidarity for newcomers to the housing community. Instead of resorting to litigation for neighbor disputes, owners' associations or residents themselves should attempt to resolve their conflicts or disputes through some amicable or non-destructive means, like mediation. Overall, the community-building approach targets the building up of the relationship between residents in a $\mathrm{MOH}$ development so they will have a stronger collective efficacy belief in tackling collective problems in the development.

Another insight derived from the analysis results is that homeowner involvement in $\mathrm{MOH}$ governance can be promoted through boosting homeowners' selective incentives of participation. To this end, the government can emphasize in the community education campaign that participation in housing governance is the direct responsibility of homeowners. When a social norm of resident participation is cultivated, homeowners of $\mathrm{MOH}$ developments will have stronger motivation to engage in the governance affairs of their neighborhoods. What is more, homeowner participation can be catalyzed by fortification of the residential attachment of homeowners. Residential attachment can be reinforced by strengthening collective sentiments within the $\mathrm{MOH}$ developments. Designing a logo or composing a song for a housing development may help, although the effect of such a collective identity building exercise has not yet been proven. In addition, creating more outdoor recreational spaces with a housing development can help residential attachment $[93,94]$.

\section{Conclusions}

Vigilant management and maintenance of housing stock is essential for a city's sustainable development $[95,96]$. This is particularly true for cities predominated by $\mathrm{MOH}$ developments. Homeowners are often held ultimately responsible for the outcomes of $\mathrm{MOH}$ governance even though they can appoint a proxy, that is, PMA, to support in the governance process. Homeowners' active engagement in $\mathrm{MOH}$ governance is, thus, indispensable for the homeowners to discharge their responsibilities. However, how the involvement of PMA in the process of $\mathrm{MOH}$ governance influences homeowner participation is an area that has long been under-researched. To fill the void in the literature, the present research attempts to examine the effect of PMA efficacy perceived by a homeowner on his or her participation level in MOH governance in Hong Kong and Macau. The analysis results of this study confirm the previous empirical findings that the participation level of a private $\mathrm{MOH}$ homeowner is contingent on his or her perceived value of the collective good to be generated, self and group efficacy beliefs, sense of residential attachment, social norm and membership in residential association committee. Moreover, a negative correlation between perceived PMA efficacy and participation level was found. Though hard to enumerate precisely, the contributions of this study are noteworthy. Several previous works have been devoted to the investigation of how an individual's actions are shaped by his or her proxy efficacy belief. Yet, private actions rather than collective actions are the research foci in nearly all of these studies. This research advances the knowledge frontier on Bandura's notion of human agency [45]. It offers us valuable empirical evidence regarding the role played by proxy efficacy belief in shaping an individual's participation behavior in a collective-action context.

Based on the findings of the research, different recommendations, have been drawn to promote homeowners' contributions to $\mathrm{MOH}$ governance through adjusting their efficacy beliefs. For instance, a community education program is needed for enhancing homeowners' capabilities in $\mathrm{MOH}$ governance and strengthening their self efficacy beliefs. Homeowners should be alerted of the disadvantages of reliance on proxy agency in $\mathrm{MOH}$ governance. Communitarian approaches should be adopted in both housing design and housing management to reinforce homeowners' collective efficacy beliefs. Given that formal institutions have been found to exert remarkable influence on collectivism in $\mathrm{MOH}$ governance [97], future studies are warranted to unravel how the institutional settings of $\mathrm{MOH}$ governance affect the relationships between different efficacy beliefs and homeowners' participation behaviors. Besides, it will be also interesting to probe the interacting dynamics of three efficacy beliefs in the context of $\mathrm{MOH}$ governance in further research. Moreover, future studies can be designed to 
investigate how the participation level varies across different governance issues such as neighbor nuisances (e.g., noise, littering and vandalism), building repair and maintenance and investment in sustainability.

Funding: The work described in this article was fully supported by a grant from the Research Grants Council of the Hong Kong Special Administrative Region, China [Project No. CityU 11410214].

Acknowledgments: An earlier version of this article was presented at the 1st Asian Social Sciences and Business Research Conference held in Macau in August 2017. The author would like to thank the delegates for their helpful comments on the earlier version of the article.

Conflicts of Interest: The author declares no conflict of interest.

\section{References}

1. Hemmens, G.C.; Hoch, C.J.; Carp, J. (Eds.) Under One Roof: Issues and Innovations in Shared Housing; State University of New York Press: Albany, NY, USA, 1996.

2. Ho, D.C.W.; Yau, Y.; Wong, S.K.; Cheung, A.K.C.; Chau, K.W.; Leung, H.F. The effects of building management regimes on building performance in Hong Kong. Prop. Manag. 2006, 24, 309-321.

3. Ho, D.C.W.; Chau, K.W.; Cheung, A.K.C.; Yau, Y.; Wong, S.K.; Leung, H.F.; Lau, S.S.Y.; Wong, W.S. A survey of the health and safety conditions of apartment buildings in Hong Kong. Build. Environ. 2008, 43, 764-775. [CrossRef]

4. Housing, Planning and Lands Bureau. Building Management and Maintenance: Public Consultation on Mandatory Building Inspection; Housing, Planning and Lands Bureau: Hong Kong, China, 2005.

5. Olson, M. The Logic of Collective Action; Harvard University Press: Cambridge, MA, USA, 1965.

6. Walters, M. Transaction costs of collective action in Hong Kong high rise real estate. Int. J. Soc. Econ. 2002, 29, 299-314. [CrossRef]

7. Walters, M.; Kent, P. Institutional economics and property strata title: A survey and case study. J. Prop. Res. 2000, 17, 221-240. [CrossRef]

8. Ariff, N.R.M.; Davis, H. Multi-owner low-cost housing management in Malaysia: Effects of owner-occupant characteristics and occupancy rates. Int. J. Hous. Mark. Anal. 2011, 4, 268-289. [CrossRef]

9. $\mathrm{Fu}, \mathrm{Q}$. Neighborhood conflicts in urban China: From consciousness of property rights to contentious actions. Eurasian Geogr. Econ. 2015, 56, 285-307. [CrossRef]

10. Shin, H.B. The rights to the city and critical reflections on China's property rights activism. Antipode 2013, 45, 1167-1189. [CrossRef]

11. Etemadi, F.U. Civil society participation in city governance in Cebu city. Environ. Urban. 2000, 12, 57-72. [CrossRef]

12. Read, B.L. Assessing variation in civil society organizations: China's homeowner associations in comparative perspective. Comp. Polit. Stud. 2008, 41, 1240-1265. [CrossRef]

13. Yau, Y. Sense of community and homeowner participation in housing management: A study of Hong Kong. Urbani Izziv 2010, 21, 126-135. [CrossRef]

14. Cho, S.; Lee, T. A study on building sustainable communities in high-rise and high-density apartments: Focused on living program. Build. Environ. 2011, 46, 1428-1435. [CrossRef]

15. Yau, Y. Willingness to participate in collective action: The case of multiowned housing management. J. Urban Aff. 2013, 35, 153-171. [CrossRef]

16. Christudason, A. Property rights: Achieving a fine balance in collective sales of strata developments in Singapore. Int. J. Law Built Environ. 2009, 1, 26-41. [CrossRef]

17. Gao, W. Collective actions for the management of multi-owned residential building: A case of Hong Kong. Habitat Int. 2015, 49, 316-324. [CrossRef]

18. Nield, S. Legal framework of deeds of mutual covenant. In Multi-Storey Building Management; Nield, S., Sihombing, J., Eds.; Hong Kong Law Journal: Hong Kong, China, 1990; pp. 1-26.

19. Bailey, N.; Robertson, D. Management of Flats in Multiple Ownership: Learning from Other Countries; Policy Press: Bristol, UK, 1997.

20. Chen, S.; Webster, C. Homeowners associations, collective action and the costs of private governance. Hous. Stud. 2005, 20, 205-220. [CrossRef] 
21. Hastings, E.M.; Wong, S.K.; Walters, M. Governance in a co-ownership environment: The management of multi-ownership property in Hong Kong. Prop. Manag. 2006, 24, 293-308. [CrossRef]

22. Loo, K.F. A Guide to Effective Property Management in Hong Kong; Hong Kong University Press: Hong Kong, China, 1991.

23. Richardson, A. Participation; Routledge: London, UK, 1984.

24. Castell, P. Managing Yards and Togetherness: Living Conditions and Social Robustness through Tenant Involvement in Open Space Management; Chalmers University of Technology: Göteborg, Sweden, 2010.

25. Churchman, A. Can resident participation in neighborhood rehabilitation programs succeed? Israel's project renewal through a comparative perspective. In Neighborhood and Community Environments; Altman, I., Wandersman, A., Eds.; Plenum Press: New York, NY, USA, 1987; pp. 113-162.

26. Dekker, K.; van Kempen, R. Places and participation: Comparing resident participation in post-WWII neighborhoods in northwest, central and southern Europe. J. Urban Aff. 2008, 30, 63-86. [CrossRef]

27. Hallman, H. Neighborhood Government in Metropolitan Settings; Sage: Beverly Hills, CA, USA, 1974.

28. Hawdon, J.; Ryan, J. Neighborhood organizations and resident assistance to police. Sociol. Forum 2011, 26, 897-920. [CrossRef]

29. Morris, D.E.; Hess, K. Neighborhood Power: The New Localism; Beacon: Boston, MA, USA, 1975.

30. Peterman, W. The meaning of resident empowerment: Why just about everyone thinks it's a good idea and what it has to do with resident management? Hous. Policy Debate 1996, 7, 473-490. [CrossRef]

31. Saegert, S.; Winkel, G.; Swartz, C. Social capital and crime in New York City's low-income housing. Hous. Policy Debate 2002, 13, 189-226. [CrossRef]

32. Ammar, S.M.S.; Ali, K.H.; Yusof, N. Effect of residents' participation in management works on satisfaction in multi-storey housing. Procedia Soc. Behav. Sci. 2012, 62, 837-843. [CrossRef]

33. Cairncross, L.; Clapham, D.; Goodlad, R. Tenant participation and tenant power in British council housing. Public Admin. 1994, 72, 177-200. [CrossRef]

34. Chandler, M.O. What have we learned from public housing resident management? J. Plan. Lit. 1991, 6, 136-143. [CrossRef]

35. Gulati, P. Consumer participation in administrative decision making. Soc. Serv. Rev. 1982, 56, 72-84. [CrossRef]

36. LeBrasseur, R.; Blackford, K.; Whissell, C. The Leford test of tenant locus of control: Introducing an effective measure relating locus of control and housing satisfaction. Environ. Behav. 1988, 20, 300-319. [CrossRef]

37. Van Rysin, G.G. The impact of resident management on residents' satisfaction with public housing: A process analysis of quasi-experimental data. Eval. Rev. 1996, 20, 485-506. [CrossRef]

38. Hovi, J.; Foss, P. The collective action problem and some of its solutions. In Economic Approaches to Organizations and Institutions; Foss, P., Ed.; Dartmouth Publishing Company: Aldershot, UK, 1995; pp. 241-256.

39. Lai, L.W.C.; Chan, P.Y.L. The formation of owners' corporations in Hong Kong's private housing estates: A probit evaluation of Mancur Olson's group theory. Prop. Manag. 2004, 22, 55-68.

40. Bengtsson, B. Solving the tenants' dilemma: Collective action and norms of co-operation in housing. Hous. Theory Soc. 2000, 17, 175-187. [CrossRef]

41. Chavis, D.M.; Wandersman, A. Sense of community in the urban environment: A catalyst for participation and community development. Am. J. Commun. Psychol. 1990, 18, 55-81. [CrossRef]

42. Unger, D.G.; Wandersman, A. Neighboring and its role in block organizations: An exploratory report. Am. J. Commun. Psychol. 1983, 11, 291-300. [CrossRef]

43. Wandersman, A.; Jakubs, J.F.; Giamartino, G.A. Participation in block organizations. J. Commun. Action 1981, 1, 40-48.

44. Stajkovic, A.D.; Luthans, F. Social cognitive theory and self-efficacy: Going beyond traditional motivational and behavioral approaches. Organ. Dyn. 1998, 26, 62-74. [CrossRef]

45. Bandura, A. Social Foundations of Thought and Action: A Social Cognitive Theory; Prentice-Hall: Englewood Cliffs, NJ, USA, 1986.

46. Bandura, A. Social cognitive theory: An agentic perspective. Annu. Rev. Psychol. 2001, 52, 1-26. [CrossRef] [PubMed]

47. Bandura, A. Social cognitive theory: An agentic perspective. Asian J. Soc. Psychol. 1999, 2, 21-41. [CrossRef]

48. Van Zomeren, M.; Postmes, T.; Spears, R. Towards an integrative social identity model of collective action: A quantitative research synthesis of three socio-psychological perspectives. Psychol. Bull. 2008, 134, 504-535. [CrossRef] [PubMed] 
49. Watson, C.B.; Chemers, M.M.; Preiser, N. Collective efficacy: A multilevel analysis. Personal. Soc. Psychol. Bull. 2001, 27, 1057-1068. [CrossRef]

50. Fernández-Ballesteros, R.; Díez-Nicolás, J.; Caprara, G.V.; Barbaranelli, C.; Bandura, A. Determinants and structural relation of personal efficacy to collective efficacy. Appl. Psychol. Int. Rev. 2002, 51, 107-125. [CrossRef]

51. Gibson, C.; Zhao, J.; Lovrich, N.; Gaffney, M. Social integration, individual perceptions of collective efficacy, and fear of crime in three cities. Justice Q. 2002, 19, 537-564. [CrossRef]

52. Sampson, R.J.; Raudenbush, S.W.; Earls, F. Neighborhoods and violent crime: A multilevel study of collective efficacy. Science 1997, 277, 918-924. [CrossRef] [PubMed]

53. Bray, S.R.; Shields, C.A. Proxy agency in physical activity. In Group Dynamics in Exercise and Sport Psychology: Contemporary Themes; Beauchamp, M.R., Eys, M.A., Eds.; Routledge: New York, NY, USA, 2007; pp. $79-95$.

54. Bray, S.R.; Gyurcsik, N.C.; Culos-Reed, S.N.; Dawson, K.A.; Martin, K.A. An exploratory investigation of the relationship between proxy efficacy, self-efficacy and exercise attendance. J. Health Psychol. 2001, 6, 425-434. [CrossRef] [PubMed]

55. Bandura, A. Self-Efficacy: The Exercise of Control; W.H. Freeman and Company: New York, NY, USA, 1997.

56. Yau, Y.; Ho, D.C.W.; Chau, K.W. Determinants of the safety performance of private multi-storey residential buildings in Hong Kong. Soc. Indic. Res. 2008, 89, 501-521. [CrossRef]

57. Ho, D.C.W.; Chau, K.W.; Yau, Y. Evaluating unauthorized appendages in private apartment buildings. Build. Res. Inf. 2008, 36, 568-579. [CrossRef]

58. Bray, S.R.; Cowan, H. Proxy efficacy: Implications for self-efficacy and exercise intentions in cardiac rehabilitation. Rehabil. Psychol. 2004, 49, 71-75. [CrossRef]

59. Bray, S.R.; Gyurcsik, N.C.; Culos-Reed, S.N. The proxy efficacy exercise questionnaire: Development of an instrument to assess female exercisers' proxy efficacy beliefs in structured group exercise classes. Exerc. Psychol. 2004, 26, 442-456. [CrossRef]

60. Elias, S.; MacDonald, S. Using past performance, proxy efficacy, and academic self-efficacy to predict college performance. J. Appl. Soc. Psychol. 2007, 37, 2518-2531. [CrossRef]

61. Priebe, C.S.; Flora, P.K.; Ferguson, L.J.; Anderson, T.J. Using efficacy information to manipulate proxy efficacy in novice exercisers. Psychol. Sport Exerc. 2012, 13, 562-568. [CrossRef]

62. Shields, C.A.; Brawley, L.R. Preferring proxy-agency: Impact on self-efficacy for exercise. J. Health Psychol. 2006, 11, 904-914. [CrossRef] [PubMed]

63. Vargas-Tonsing, T.M.; Warners, A.L.; Feltz, D.L. The predictability of coaching efficacy on team efficacy and player efficacy in volleyball. J. Sport Behav. 2003, 26, 396-407.

64. Fowles, J.R.; Shields, C.; d'Entremont, L.; McQuaid, S.; Barron, B.; Dunbar, P. Implementation of resources to support patient physical activity through diabetes centres in Nova Scotia: The effectiveness of enhanced support for exercise participation. Can. J. Diabetes 2014, 38, 423-431. [CrossRef] [PubMed]

65. Riker, W.; Ordeshook, P. A theory of the calculus of voting. Am. Polit. Sci. Rev. 1968, 62, 25-42. [CrossRef]

66. Muller, E.N.; Opp, K.D. Rational choice and rebellious collective action. Am. Polit. Sci. Rev. 1986, 80, 471-488. [CrossRef]

67. Finkel, S.E.; Muller, E.N. Rational choice and the dynamics of political action: Evaluating alternative models with panel data. Am. Polit. Sci. Rev. 1998, 92, 37-49. [CrossRef]

68. Finkel, S.E.; Muller, E.N.; Opp, K.D. Personal influence, collective rationality, and mass political action. Am. Polit. Sci. Rev. 1989, 83, 885-903. [CrossRef]

69. Muller, E.N.; Dietz, H.A.; Finkel, S.E. Discontent and the expected utility of rebellion: The case of Peru. Am. Polit. Sci. Rev. 1991, 85, 1261-1282. [CrossRef]

70. Lubell, M.; Zahran, S.; Vedlitz, A. Collective action and citizen responses to global warming. Polit. Behav. 2007, 29, 391-413. [CrossRef]

71. Weible, C.M. A collective interest model approach to explain the benefit-cost expectations of participating in a collaborative institution. Environ. Behav. 2008, 40, 24-45. [CrossRef]

72. Bäck, H.; Teorell, J.; Westholm, A. Explaining modes of participation: An evaluation of alternative theoretical models. In Proceedings of the European Consortium for Political Research Joint Sessions of Workshops, Uppsala, MN, USA, 13-18 April 2004.

73. Lubell, M. Environmental activism as collective action. Environ. Behav. 2002, 34, 431-454. [CrossRef] 
74. Lubell, M.; Vedlitz, A.; Zahran, S.; Alston, L. Collective action, environmental activism, and air quality policy. Polit. Res. Q. 2006, 59, 149-160. [CrossRef]

75. Niemiec, R.M.; Ardoin, N.M.; Wharton, C.B.; Asner, G.P. Motivating residents to combat invasive species on private lands: Social norms and community reciprocity. Ecol. Soc. 2016, 21, 30-39. [CrossRef]

76. Yau, Y. Collectivism and activism in housing management in Hong Kong. Habitat Int. 2011, 35, 327-334. [CrossRef]

77. Preisendörfer, P. Personal exposure to unfavorable environmental conditions: Does it stimulate environmental activism? In Social Dilemmas, Institutions, and the Evolution of Cooperation; Jann, B., Przepiorka, W., Eds.; De Gruyter: Berlin, Germany, 2017; pp. 143-155.

78. Eagle, S.J. Environmental amenities, private property, and public policy. Nat. Resour. J. 2004, 44, 425-444.

79. Graves, P.E. A note on the valuation of collective goods: Overlooked input market free riding for non-individually incrementable goods. B.E. J. Econ. Anal. Policy 2009, 9, 5. [CrossRef]

80. Sargent, L.D.; Sue-Chan, C. Does diversity affect group efficacy: The intervening role of cohesion and task interdependence. Small Group Res. 2001, 32, 426-450. [CrossRef]

81. Hidalgo, M.C.; Hernández, B. Place attachment: Conceptual and empirical questions. J. Environ. Psychol. 2001, 21, 273-281. [CrossRef]

82. Massey, D. The political place of locality studies. Environ. Plan. A 1991, 23, 267-282. [CrossRef]

83. Dekker, K. Social capital, neighbourhood attachment and participation in distressed urban areas: A case study in the Hague and Utrecht, the Netherlands. Hous. Stud. 2007, 22, 355-379. [CrossRef]

84. Tajfel, H.; Turner, J. An integrative theory of intergroup conflict. In Psychology of Intergroup Relations; Worchel, S., Austin, W., Eds.; Brooks: Pacific Grove, CA, USA, 1979; pp. 33-47.

85. Brady, H.E.; Verba, S.; Schlozman, K.L. Beyond SES: A resource of political participation. Am. Polit. Sci. Rev. 1995, 89, 271-294. [CrossRef]

86. Dilger, R.J. Neighborhood Politics: Residential Community Associations in American Governance; University Press: New York, NY, USA, 1992.

87. Lavrakas, P.J.; Herz, E.J. Citizen participation in neighborhood crime prevention. Criminology 1982, 20, 479-498. [CrossRef]

88. Silver, H.; Scott, A.; Kazepov, Y. Participation in urban contention and deliberation. Int. J. Urban Reg. Res. 2010, 34, 453-477. [CrossRef]

89. Yau, Y. Homeowners' participation in management of multi-storey residential buildings: The Hong Kong's case. Prop. Manag. 2011, 29, 345-356. [CrossRef]

90. Dunlop, W.; Beatty, D.; Beauchamp, M.R. Examining the influence of other-efficacy and self-efficacy on personal performance. J. Sport Exerc. Psychol. 2011, 33, 586-593. [CrossRef] [PubMed]

91. Shields, C.A.; Brawley, L.R. Limiting exercise options: Depending on a proxy may inhibit exercise self-management. J. Health Psychol. 2007, 12, 663-671. [CrossRef] [PubMed]

92. Bray, S.R.; Shields, C.A.; Jackson, B.; Saville, P.D. Proxy agency and other-efficacy in physical activity. In Group Dynamics in Exercise and Sport Psychology, 2nd ed.; Beauchamp, M., Eys, M., Eds.; Routledge: London, UK, 2014; pp. 91-109.

93. Mantey, D. The role of public spaces in creating place attachment. Miscellanea Geogr. 2015, 19, 36-42. [CrossRef]

94. Schroeder, H.W. Preference and meaning of arboretum landscapes: Combining quantitative and qualitative data. J. Environ. Psychol. 1991, 11, 231-248. [CrossRef]

95. Yau, Y.; Lau, W.K. Big data approach as institutional innovation to tackle Hong Kong's illegal subdivided unit problem. Sustainability 2018, 10, 2709. [CrossRef]

96. Lind, H.; Annadotter, K.; Björk, F.; Högberg, L.; Af Klintberg, T. Sustainable renovation strategy in the Swedish Million Homes Programme: A case study. Sustainability 2016, 8, 388. [CrossRef]

97. Donoso, R.E.; Elsinga, M. Management of low-income condominiums in Bogotá and Quito: The balance between property law and self-organisation. Int. J. Hous. Policy 2018, 18, 312-334. [CrossRef]

(C) 2018 by the author. Licensee MDPI, Basel, Switzerland. This article is an open access article distributed under the terms and conditions of the Creative Commons Attribution (CC BY) license (http:/ / creativecommons.org/licenses/by/4.0/). 